Terbit online pada laman: http://teknosi.fti.unand.ac.id/

\title{
Pembuatan Aplikasi Web dan Mobile Untuk Sistem Informasi Pengelolaan Aset dengan QR Code (Studi Kasus: PT Kereta Api Indonesia (Persero) Divisi Regional II Sumatera Barat)
}

\author{
Ricky Akbar $^{a}$ Arif Rahman ${ }^{b}$ \\ ${ }^{a}$ Jurusan Sistem Informasi Fakultas Teknologi Informasi Universitas Andalas \\ ${ }^{b}$ Jurusan Sistem Informasi Fakultas Teknologi Informasi Universitas Andalas
}

\begin{tabular}{|c|}
\hline INFORMASI ARTIKEL \\
\hline $\begin{array}{l}\text { Sejarah Artikel: } \\
\text { Diterima Redaksi: } 15 \text { Juli } 2020 \\
\text { Revisi Akhir: } 18 \text { November } 2020 \\
\text { Diterbitkan Online: } 31 \text { Desember } 2020\end{array}$ \\
\hline KATA KUNCI \\
\hline $\begin{array}{l}\text { QR Code Aset, } \\
\text { aplikasi web dan mobile }\end{array}$ \\
\hline KORESPONDENSI \\
\hline E-mail: rickyakbar1984@gmail.com \\
\hline
\end{tabular}

\begin{abstract}
A $\quad$ B $\quad S \quad T \quad R \quad A \quad C \quad T$
Sistem pengelolaan aset yang terjadi selama ini di PT Kereta Api Indonesia (Persero) Divisi Regional II Sumatera Barat, masih dilakukan secara konvensional. Yaitu dengan mendata satu per satu aset yang ada kemudian di catat pada sebuah kertas. Untuk merekap catatan pada kertas digunakan MS Excel. Sistem manual seperti ini tentu memiliki banyak masalah nantinya, misalkan jika hilangnya catatan pada kertas tadi, maka harus di lakukan pendataaan ulang, hal ini tentu akan membutuhkan waktu yang lama. Melihat perkembangan Teknologi Informasi saat ini, perlu dilakukan pembuatan aplikasi web dan mobile dalam mengelola system informasi aset tadi. Apalagi dilakukan dengan memanfaatkan tekologi QR Code yang dapat lebih mempermudah dalam mendata aset dengan hanya melakukan pemindaian terhadap label $\mathrm{QR}$ Code yang terpasang pada masing-masing aset. Sehingga proses dalam mendata atau melakukan pengelolaan aset dapat berjalan dengan akurat dan cepat. Maka dilakukan penelitian untuk pembuatan aplikasi aset ini dengan menggunakan metode pengembangan system yaitu metode waterfall, yang meliputi tahapan analisis, perancangan, coding dan testing. Adapun luaran dari penelitian adalah terciptanya sebuah aplikasi web dan mobile untuk mengelola system informasi aset dengan memanfaatkan teknologi QR Code.
\end{abstract}

\section{PENDAHULUAN}

Pengelolaan aset merupakan suatu proses untuk perbaikan pemahaman kondisi aset, perbaikan biaya operasi, dan kinerja yang membantu perbaikan dalam proses pengambilan keputusan bagi suatu perusahaan [1]. Pengelolaan aset menjadi penting dalam keberlangsungan hidup perusahaan karena berpengaruh pada kinerja dan pelayanan perusahaan itu sendiri. Selama ini pengelolaan aset yang dilakukan oleh PT Kereta Api Indonesia (Persero) Divisi Regional II Sumatera Barat yang mempunyai tugas pokok untuk menjaga dan meningkatkan kualitas sumber daya, salah satunya adalah sumber daya aset sebagai alat penunjang kebutuhan perusahaan [2], masih dilakukan secara konvensional. Yaitu dengan mendata satu per satu aset yang ada kemudian di catat pada sebuah kertas yang disebut kartu kendali aset. Untuk merekap catatan pada kartu kendali ini digunakan MS Excel. Sistem manual seperti ini tentu memiliki banyak masalah nantinya, misalkan jika hilangnya catatan pada kertas atau kartu kendali tadi, maka harus di lakukan pendataaan ulang, hal ini tentu akan membutuhkan waktu yang lama, kemudian perekapan di MS Excel juga bisa saja terjadi kesalahan yang cukup besar dalam memasukkan datanya. Sehingga diperlukan system pengelolaan aset yang lebih handal dengan memanfaatkan perkembangan teknologi informasi.

Sistem informasi pengelolaan aset berperan dalam pengelolaan aset yang dapat mempercepat dan mempermudah pendataan dan pengawasan aset. Pemanfaatan teknologi informasi dalam pengeloalaan sumber daya aset saat sekarang ini sudah banyak memanfaatkan teknologi QR Code. Teknologi Quick Response Code atau $Q R$ Code dianggap sebagai cara yang inovatif dan 
dapat memberi kemudahan dalam berbagai kegiatan sistem yang ada karena memberikan kecepatan pendataan. $Q R$ Code sendiri adalah image dua dimensi yang merepresentasikan suatu data, terutama data berbentuk text [3]. QR Code memiliki berbagai keunggulan dalam penyimpanan dan pemanfaatan data serta keunggulan fisik yang dapat bertahan lama [4]. QR Code juga mampu memperbaiki kesalahan sampai dengan 30\%. Oleh karena itu, walaupun sebagian simbol QR Code kotor ataupun rusak, data tetap dapat disimpan dan dibaca [5]. Berbeda jika dibandingkan dengan teknologi serupa seperti barcode, karena barcode ini jika ada sebagian kode yang kotor ataupun rusak akan sangat susah untuk dibaca. Kemudian untuk pemindaian atau pembacaan kodenya biasanya barcode ini memerlukan alat khusus yaitu barcode reader. Artinya kita memerlukan biaya untuk melakukan proses pembacaanya. Sementara untuk QR Code ini tidak perlu peralatan tadi, kita hanya cukup menggunakan kamera biasa yang sudah ditanamkan aplikasi khusus untuk pembacaan kodenya. Apalagi saat ini teknologi $Q R$ Code telah didukung banyak model aplikasi seperti aplikasi web dan mobile.

Secara umum Prosedur pembangkitan $Q R$ Code dari sebuah teks dapat dijelaskan dengan diagram alir pada gambar 1 .

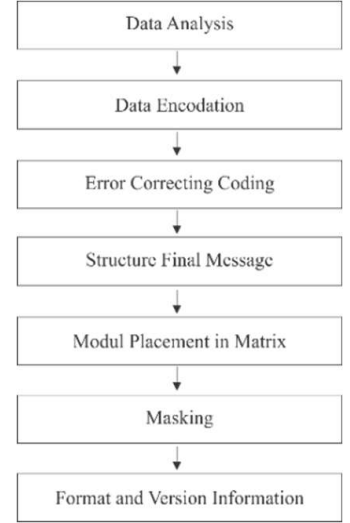

Gambar 1. Diagram alir pembangkitan QRCode [12]

Langkah-langkah untuk membaca $Q R$ Code menjadi teks aslinya merupakan reverse atau kebalikan dari langkah-langkah pada pembangkitan $Q R$ Code. Secara umum prosedur pembacaan $Q R$ Code dapat dijelaskan dengan diagram alir pada gambar 2.

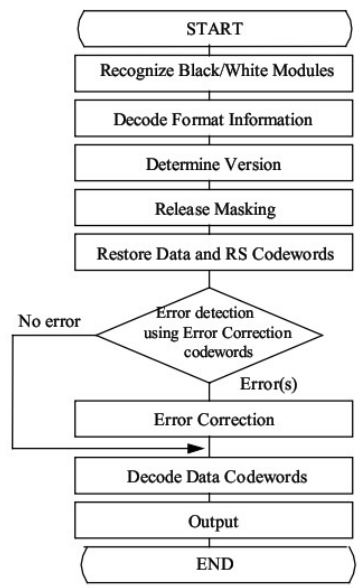

Gambar 2. Diagram alir proses pembacaan $Q R$ Code [12]

Beberapa penelitian yang sudah menerapkan Sistem Informasi pengelolaan aset dan pemanfaatan tekonlogi QR Code ini antara

130 Ricky Akbar lain, penelitian tentang Rancang Bangun Sistem Informasi Manajemen Aset Sekolah Menggunakan Teknik Labelling QR Code (Studi Kasus: MAN 2 Model Pekanbaru). Penelitian ini bertujuan untuk membangun sistem informasi manajemen aset sekolah dengan teknik labelling $Q R$ Code sebagai upaya tertib dokumen dan tertib administrasi pengelolaan aset di MAN 2 Model Pekanbaru [6]. Selain itu penggunaan QR Code juga bisa dimanfaatkan untuk kegiatan lain, seperti penelitian tentang Perancangan Model Bisnis Pembayaran Non Tunai untuk Pengelolaan Transaksi Jasa Laundry pada Tiara Laundry Padang [7]. Penelitian ini bertujuan untuk mempermudah transaksi pembayaran non tunai dengan memanfaatkankan teknologi QR Code dalam proses pembayarannya.

Berdasarkan permasalahan dan uraian diatas maka dengan penelitian ini dapat dibuat suatu aplikasi web dan mobile untuk mengelola system informasi Aset yang ada pada PT Kereta Api Indonesia (Persero) Divisi Regional II Sumatera Barat dengan memanfaatkan keunggulan dari teknologi QR Code. Sehingga system pengelolaan aset yang dilakukan pada perusahaan tersebut dapat berjalan dengan cepat, akurat dan meminimalisir segala kesalahan yang mungkin terjadi. Dengan begitu pihak manajemen dapat dengan mudah dan cepat dalam mengambil keputusan terkait pengeloalan aset untuk masa yang akan datang.

\section{METODE}

Metode pengembangan sistem yang digunakan adalah waterfall. Metode waterfall merupakan salah satu model linear sequential yang memiliki tahapan pengembangan sistem seperti: analysis, design, coding, dan testing [8]. Kelebihan dari metode waterfall ini adalah pengaplikasiannya mudah, jika semua kebutuhan sistem dapat didefinisikan secara utuh, eksplisit, dan benar diawal proyek maka software engineering (SE) dapat berjalan dengan baik dan tanpa masalah. Kekurangan dari model waterfall adalah kesulitan dalam mengakomodasi perubahan setelah proses dijalani. Fase sebelumnya harus lengkap dan selesai sebelum mengerjakan fase selanjutnya [9]. Pemodelan dari metode tersebut dapat dilihat pada Gambar 3.

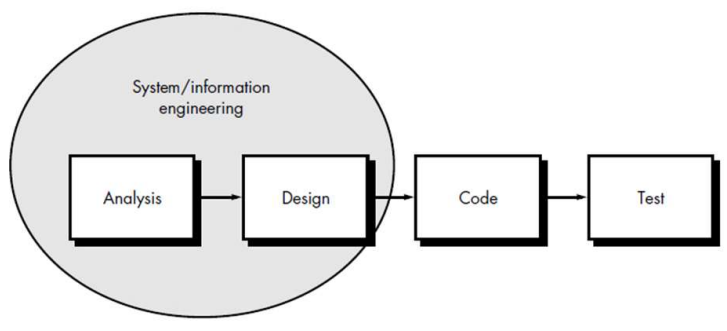

Gambar 3. Metode Waterfall [10]

Tahapan pertama dalam metode waterfall adalah tahapan analysis (analisis). Tahapan ini dilakukan untuk mengidentifikasi dan mengumpulkan kebutuhan yang membantu tim teknikal untuk memahami konteks bisnis dari sebuah aplikasi.Tahapan ini juga mendefinisikan output yang akan dihasilkan, fitur yang dimiliki oleh aplikasi dan fungsi dari aplikasi yang dikembangkan. Selanjutnya pada tahapan design (perancangan) dilakukan perancangan aplikasi dari hasil perencanaan. Tahapan ini menekankan pada perancangan basis data dan desain antarmuka aplikasi yang sederhana. Pada tahapan coding 
(pengkodean) dilakukan translasi hasil desain ke dalam program perangkat lunak. Tahapan coding akan menghasilkan program komputer atau aplikasi berdasarkan alur sistem, basisdata (database) dan desain antarmuka (user interface) aplikasi yang telah dirancang pada tahap desain. Selanjutnya tahapan testing (pengujian) berfokus pada pengujian perangkat lunak dari segi logic dan fungsional serta memastikan semua bagian sudah diuji. Hal ini dilakukan untuk meminimalisir kesalahan (error) dan memastikan keluaran yang dihasilkan sesuai yang diinginkan [11]. Dalam penelitian ini pengujian sistem yang digunakan adalah pengujian Black-box. Metode pengujian Black-box berfokus pada persyaratan fungsional perangkat lunak sehingga memungkinkan perekayasa perangkat lunak mendapatkan serangkaian kondisi input yang sepenuhnya menggunakan samua persyaratan fungsional untuk suatu program.

\section{ANALISIS DAN PERANCANGAN}

Bagian ini menjelaskan analisis dan perancangan dari sistem yang dibangun. Hasil analisis ditampilkan dalam bentuk Business Process Model Notation (BPMN), analisis kebutuhan fungsional sistem, use case diagram, use case scenario, sequence diagram, dan class analysis. Sedangkan pada perancangan sistem terdiri dari perancangan database, struktur tabel dan basis data, arsitektur aplikasi, class diagram, dan user interface.

\subsection{Analisis Sistem}

Tahapan analisis sistem menjelaskan tentang kedudukan sistem saat ini, sistem yang diusulkan, dan analisis sistem yang dimodelkan menggunakan UML (Unified Modelling Language). UML yang digunakan untuk analisis sistem ini adalah use case diagram, use case scenario, sequence diagram, class analysis dan class diagram.

\subsubsection{Kedudukan Sistem}

Sistem informasi manajemen aset yang sedang berjalan pada PT Kereta Api Indonesia (Persero) Divisi Regional II Sumatera Barat terdiri dari empat sub sistem, yaitu pengadaan dan permintaan aset, penempatan dan mutasi aset, peminjaman aset, dan perawatan aset. Kegiatan pengelolaan aset berpusat pada Bagian Umum Organisasi. Kegiatan pengelolaan aset yang berjalan saat ini belum memiliki sistem informasi dan tidak terintegrasi dengan semua bidang yang ada. Pendataan dan pengecekan aset dilakukan dengan menggunakan kartu kendali aset, dimana petugas melakukan proses tersebut ke masing-masing bidang lalu memberikan data yang ada kepada bagian pencatatan di Bagian Umum. Seluruh data pengelolaan aset yang dihasilkan dari kartu kendali aset, kemudian direkap dan dijadikan laporan aset dengan menggunakan Microsoft Excel yang menyajikan data kondisi aset, dan pengelolaan aset yang terjadi. Oleh karena itu, pada penelitian ini dibuat sistem informasi berbasis web dan mobile yang bertujuan untuk mengelola proses manajemen aset dengan memanfaatkan teknologi $Q R$ Code yang terintegrasi dengan seluruh bidang pada PT Kereta Api Indonesia (Persero) Divisi Regional II Sumatera Barat.

\subsubsection{Sistem yang Berjalan}

Sistem informasi manajemen aset yang berjalan di PT Kereta Api Indonesia (Persero) Divisi Regional II Sumatera Barat dimodelkan dengan menggunakan Business Process Model Notation (BPMN). Salah satu proses yang berjalan adalah proses perawatan aset. Alur proses perawatan aset yang sedang berjalan dapat dilihat pada Gambar 4.

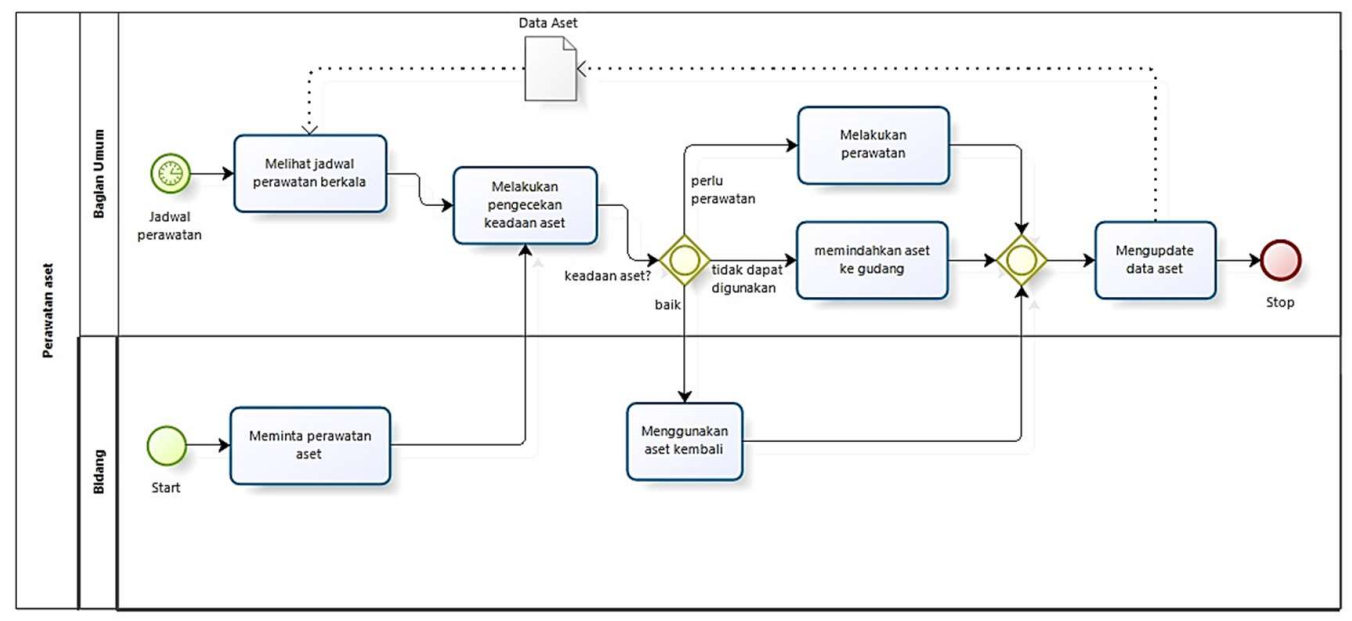

Gambar 4. BPMN Proses Perawatan aset yang berjalan

Berikut ini penjelasan dari Gambar 4 mengenai BPMN perawatan aset yang berjalan :

1. Bidang meminta perawatan aset kepada Bagian Umum untuk dilakukan pengecekan.

2. Bagian Umum melihat jadwal perawatan berkala aset dan mendapat permintaan perawatan aset dari bidang.

3. Bagian Umum melakukan pengecekan terhadap aset. Jika keadaan aset baik maka aset tersebut digunakan kembali oleh bidang. Jika keadaan aset tidak dapat digunakan maka aset dipindahkan ke gudang. Jika aset perlu perawatan maka Bagian Umum melakukan perawatan terhadap aset.

4. Bagian Umum melakukan update data aset.

\subsubsection{Sistem yang Diusulkan}

Sistem informasi manajemen aset yang diusulkan dalam analisis sistem ini dimodelkan dengan menggunakan Business Process Model and Notation (BPMN). Salah satu alur sistem yang diusulkan adalah proses perawatan aset berkala. BPMN proses 
perawatan aset berkala yang diusulkan dapat dilihat pada Gambar

5.

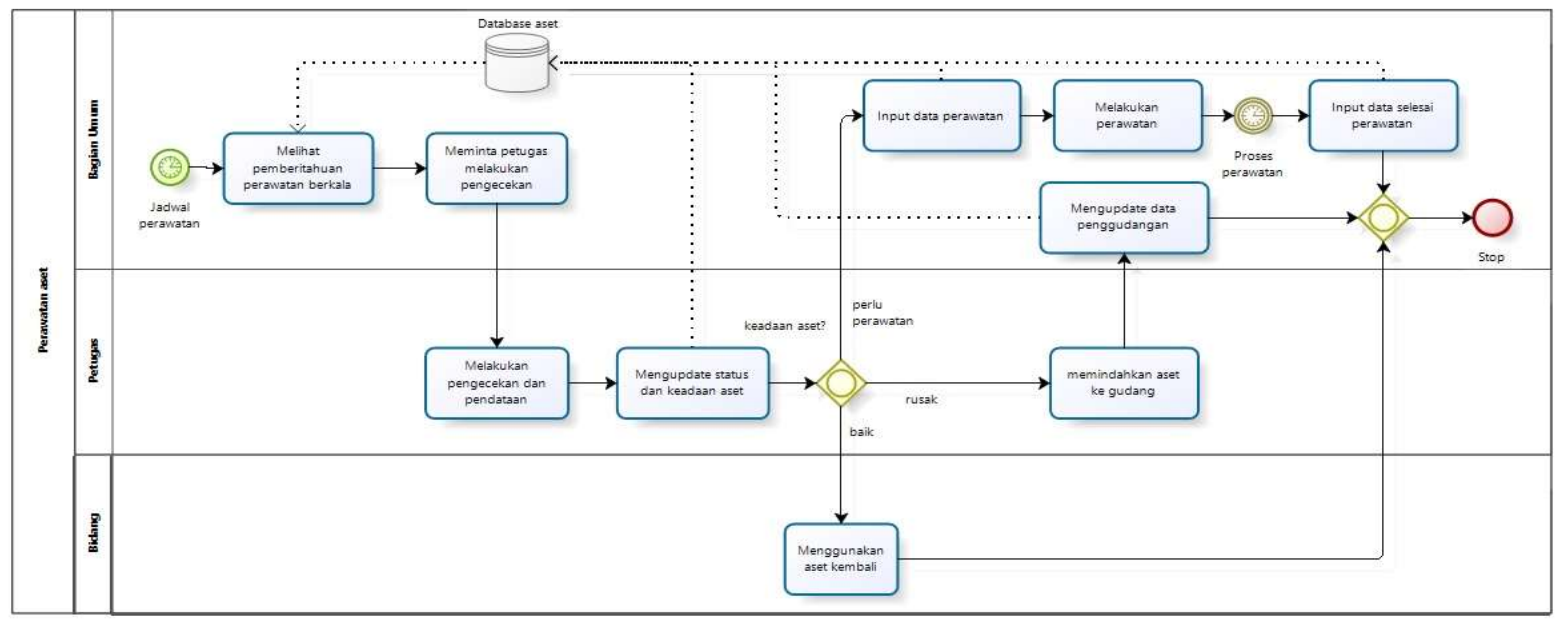

Gambar 5. BPMN Proses Perawatan Aset Berkala yang Diusulkan

Berikut ini penjelasan dari Gambar 5 mengenai proses perawatan aset berkala yang diusulkan:

1. Bagian Umum mendapat pemberitahuan berkala dari jadwal perawatan aset yang telah ditentukan.

2. Bagian Umum meminta petugas melakukan pengecekan aset.

3. Petugas melakukan pendataan dan pengecekan aset menggunakan teknologi $Q R$ Code ke bidang.

4. Jika keadaan aset baik maka aset tersebut digunakan kembali oleh bidang.

5. Jika keadaan aset rusak maka aset dipindahkan ke gudang dan Bagian Umum melakukan update data penggudangan.

6. Jika aset perlu perawatan maka Bagian Umum menginput data perawatan dan melakukan proses perawatan. Ketika perawatan telah selesai maka Bagian Umum menginputkan data selesai perawatan

\subsubsection{Analisis Kebutuhan Fungsional}

Berdasarkan analisis alur proses sistem informasi manajemen aset dengan pemanfaatan teknologi $Q R$ Code yang diusulkan maka dapat dirumuskan beberapa kebutuhan fungsionalnya yaitu:

1. Super admin dapat melihat seluruh data aset dan $Q R$ Code aset.

2. Super admin dapat mengelola data pengadaan aset yang telah terjadi.

3. Super admin dapat mengelola seluruh data penempatan, mutasi dan penggudangan aset sehingga masing-masing bagian organisasi yang menggunakan aset dapat mengetahui aset yang dimiliki.

4. Super admin dapat mengelola data peminjaman, perawatan, dan kehilangan aset.

5. Super admin dapat mengelola data referensi yang dibutuhkan seperti data user, supplier dan pegawai ke dalam database aset.

6. Super admin dapat mencetak $Q R$ Code dan laporan aset pada periode tertentu.
7. Masing-masing admin bidang aset dapat melihat aset yang dimiliki dan dapat meminta perawatan aset.

8. Masing-masing admin bidang aset dapat mengelola data permintaan aset yang dibutuhkan.

9. Petugas dapat melihat data aset melalui mobile.

10. Petugas dapat melakukan scanning $Q R$ Code dan menginput data pengecekan, peminjaman, dan pengembalian aset serta dapat mengubah keadaan aset melalui mobile.

\subsubsection{Use Case Diagram}

Setiap fungsional yang terdapat pada sistem merupakan proses yang secara teknis dilakukan oleh aktor yang terlibat di dalam sistem. Hubungan antara fungsional dengan aktor yang terlibat digambarkan dengan use case diagram. Use case diagram perancangan aplikasi ini dapat dilihat pada Gambar 6 .

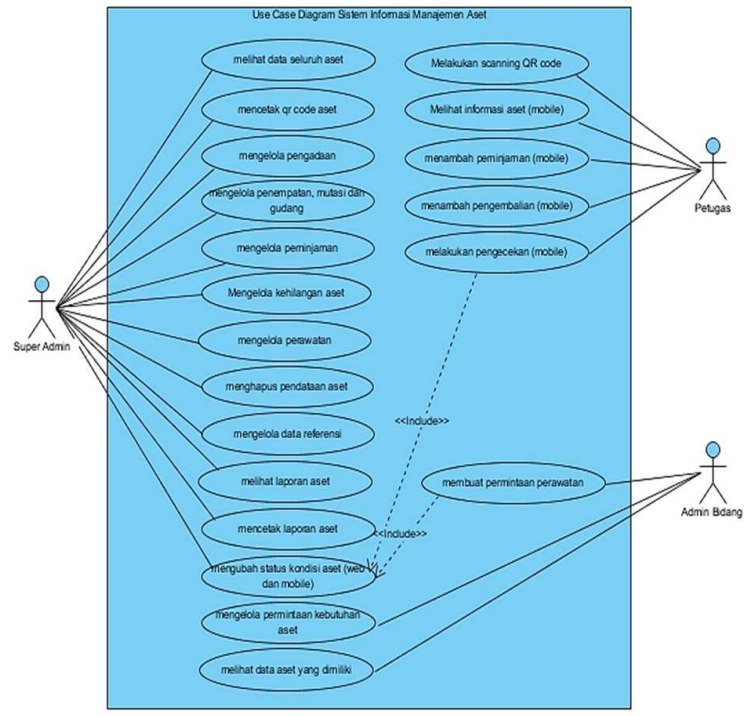

Gambar 6. Use Case Diagram 
Berdasarkan use case diagram perancangan aplikasi pada Gambar 6 didapatkan dua aktor pada aplikasi web, yaitu super admin dan admin bidang, dan satu actor pada aplikasi mobile, yaitu petugas. Terdapat dua puluh fungsional yang memiliki hubungan sesuai dengan fungsi dari masing-masing aktor. Setiap aktor diharuskan untuk login sebelum menggunakan sistem.

\subsubsection{Use Case Scenario}

Use case scenario ini menjelaskan langkah-langkah user dalam menggunakan fungsional yang ada pada sistem. Salah satu use case scenario yang dirancang adalah membuat permintaan perawatan. Use case scenario membuat permintaan perawatan aset dapat dilihat pada Tabel 1.

\subsubsection{Sequence Diagram}

Sequence diagram dibuat berdasarkan hasil analisis use case diagram, dan kemudian dikembangkan sampai dengan proses terkecil yang ada pada setiap use case. Pada proses ini diasumsikan bahwa user telah melakukan login terlebih dahulu sebelum masuk proses berikutnya. Salah satu sequence diagram yang dirancang adalah mengelola perawatan (selesai perbaikan aset). Use Case mengelola perawatan (selesai perbaikan aset) dapat dilihat pada Gambar 7.
Tabel 1. Use Case Scenario Permintaan Perawatan

\begin{tabular}{lcl}
\hline Use Case & Membuat Permintaan Perawatan \\
\hline Actor & Admin Bidang \\
Entry Condition & Actor telah login \\
Flow of Event & 1. & Actor membuka menu "Data Aset" \\
& 2. & Sistem memanggil data aset \\
& & yang dimiliki bidang \\
& 3. & Sistem menampilkan \\
& halaman data aset
\end{tabular}

4. Actor memilih tombol "Perbaiki" pada data terpilih

5. Sistem menampilkan pesan konfirmasi permintaan perawatan

6. Actor menekan tombol "Ya"

7. Sistem menjalankan query "ubahstatus()"

8. Sistem menampilkan notifikasi berhasil

Scenario

Alternatif

Exit Condition Sistem menampilkan halaman data aset

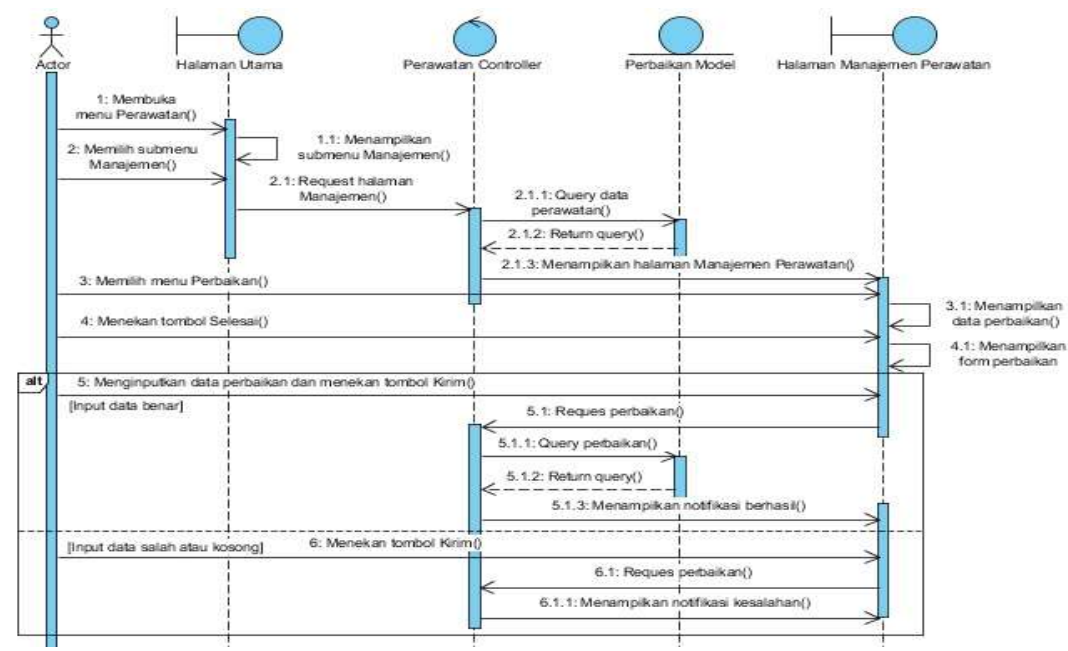

Gambar 7. Sequence Diagram mengelola perawatan (selesai perbaikan aset)

Berdasarkan Gambar 7 dapat dijelaskan bahwa proses mengelola perawatan (selesai perbaikan aset) dilakukan oleh super admin. Proses ini dimulai dengan user membuka menu "Perawatan". Kemudian sistem meminta data perawatan kepada controller dan memanggil query "dataperawatan()" dari database. Selanjutnya controller menjalankan query menampilkan data perawatan pada halaman manajemen perawatan. Proses berlangsung sampai user menekan tombol selesai dan menampilkan form perbaikan. Setelah itu melakukan input data perbaikan. Jika input sesuai dengan semestinya maka muncul notifikasi data berhasil disimpan. Namun jika kondisi input data salah atau kosong maka muncul notifikasi kesalahan pada halaman manajemen perawatan.

\subsubsection{Class Analysis}

Class analysis berfungsi untuk menggambarkan semua kelas yang terlibat di dalam setiap proses dan dibuat berdasarkan sequence diagram sistem yang telah dirancang. Salah satu class analysis yang dirancang adalah mengelola perawatan aset. Class analysis mengelola perawatan aset dapat dilihat pada Gambar 8 . 


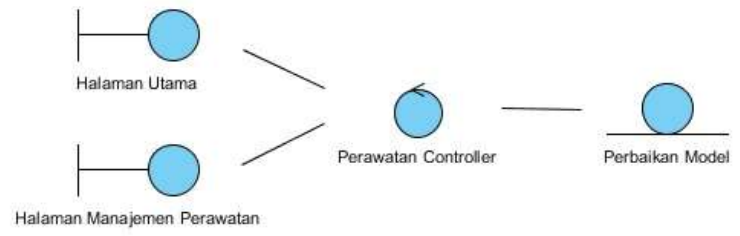

Gambar 8. Class Analysis Tambah Data Pengadaan

Berdasarkan Gambar 8 dapat dijelaskan bahwa class analysis mengelola perawatan aset terdiri atas dua halaman, yaitu halaman utama dan halaman manajemen perawatan. Pengelolaan data diproses oleh PerawatanController untuk kemudian dikirim dan disimpan kedalam perbaikan model.

\subsection{Perancangan Sistem}

Berdasarkan tahapan analisis proses bisnis yang sedang berjalan, alur sistem, dan kebutuhan sistem informasi yang dibangun maka diperoleh hasil yang menjadi dasar dan tolak ukur untuk melakukan perancangan sistem. Perancangan sistem ini meliputi perancangan database, struktur tabel dan basis data, arsitektur aplikasi, class diagram, dan antarmuka (user interface).

\subsubsection{Perancangan Database}

Perancangan database dimulai dengan menyusun struktur database berdasarkan entitas yang digunakan dan hubungannya dengan entitas-entitas lain (ERD). Perancangan database aplikasi yang dibangun dapat dilihat pada Gambar 9.

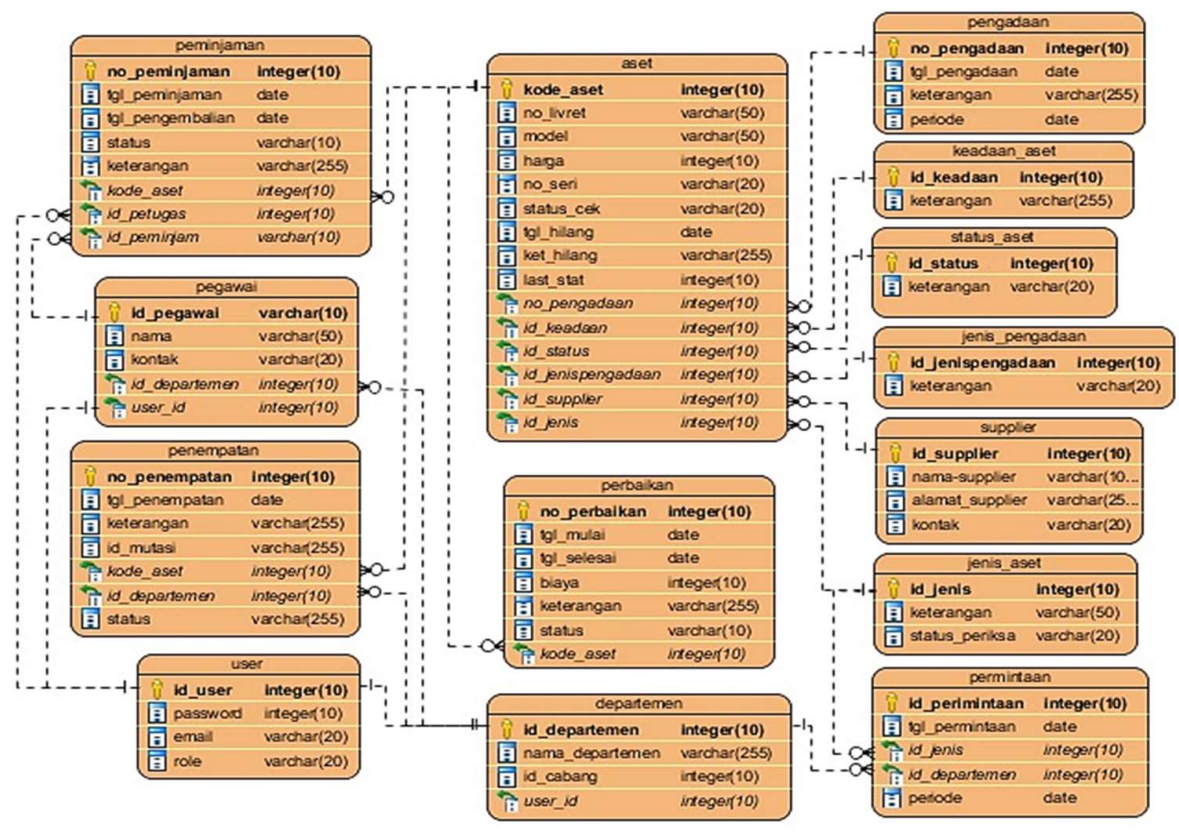

Gambar 9. Rancangan ERD

Berdasarkan Gambar 9 terlihat bahwa ERD yang dirancang terdiri dari empat belas tabel, yaitu tabel user, peminjaman, pegawai, penempatan, departemen, aset, perbaikan, permintaan, pengadaan, keadaan_aset, status_aset, jenis_pengadaan, supplier, dan jenis_aset.

\subsubsection{Struktur Tabel dan Basis Data}

Struktur tabel dan basis data merupakan representasi tabel pada masing-masing relasi beserta status atributnya. Status tersebut berupa primary key, foreign key, tipe data, nama atribut, dan nama tabel. Berikut merupakan uraian tabel pengadaan pada Tabel 2.

\subsubsection{Arsitektur Aplikasi}

Arsitektur aplikasi yang digunakan dalam perancangan dan pembangunan sistem informasi ini adalah arsitektur aplikasi
MVC (Model View Controller) dengan metode OOP (Object Oriented Programming) menggunakan framework Laravel untuk pembangunan aplikasi web dan Android Studio untuk pembangunan aplikasi mobile. Arsitektur pembangunan aplikasi dapat dilihat pada Gambar 10.

Tabel 2. Tabel Pengadaan

\begin{tabular}{lll}
\hline \multicolumn{1}{c}{ Nama atribut } & \multicolumn{1}{c}{ Tipe data } & Keterangan \\
\hline no_pengadaan & integer & PK \\
tgl_pengadaan & date & \\
keterangan & varchar & \\
periode & year & \\
\hline
\end{tabular}




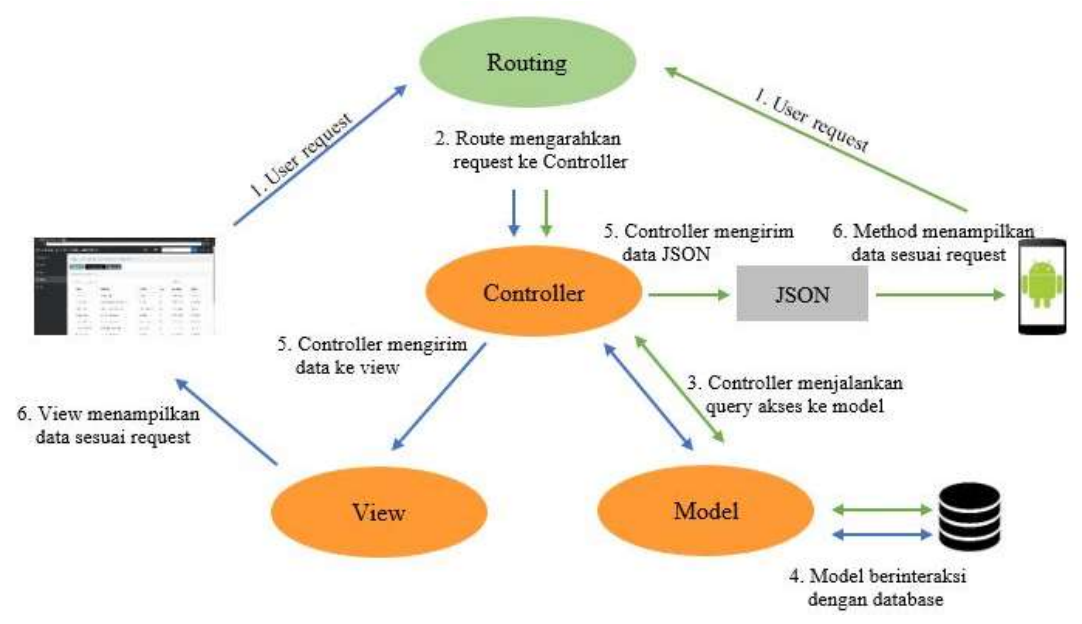

Gambar 10. Arsitektur Aplikasi

Berdasarkan Gambar 10 mengenai arsitektur aplikasi terlihat bahwa pada perancangan aplikasi web digunakan arsitektur yang memisahkan antara data (model), tampilan antar muka (view), dan pengarah (controller). Ketika user melakukan permintaan (request) terhadap sistem, maka routing akan mengarahkan kepada controller bersama dengan method yang dibutuhkan. Controller akan memanggil data melalui model. Kemudian model berinteraksi dan mengambil data dari database. Data yang didapatkan model dikirim kembali ke controller untuk kemudian ditampilkan oleh view ke halaman user.

Perancangan aplikasi mobile terbagi atas dua komponen, yaitu design dan method. Ketika user melakukan permintaan (request) terhadap sistem, maka method dijalankan untuk menghandle perintah tersebut dan mengarahkan ke routing. Routing melakukan pemanggilan ke controller untuk meminta data melalui model. Model berinteraksi dengan database dan mengirim data ke controller. Kemudian controller mengirim data berupa JSON kepada method untuk ditampilkan oleh design ke halaman user.

\subsubsection{Class Diagram}

Class diagram merupakan gambaran mengenai struktur kelaskelas dari suatu sistem dan merupakan salah satu diagram yang banyak dipakai. Pada class diagram terdapat view, model, dan controller. Class diagram juga memaparkan atribut dari masingmasing kelas beserta fungsi-fungsi yang terkandung didalamnya. Fungsi yang ada pada masing-masing kelas memiliki tugas tersendiri sesuai kebutuhan sistem. Untuk membangun sistem yang terintegrasi, masing-masing kelas memiliki relasi dengan kelas lainnya. Class diagram aplikasi dapat dilihat pada Gambar 11.

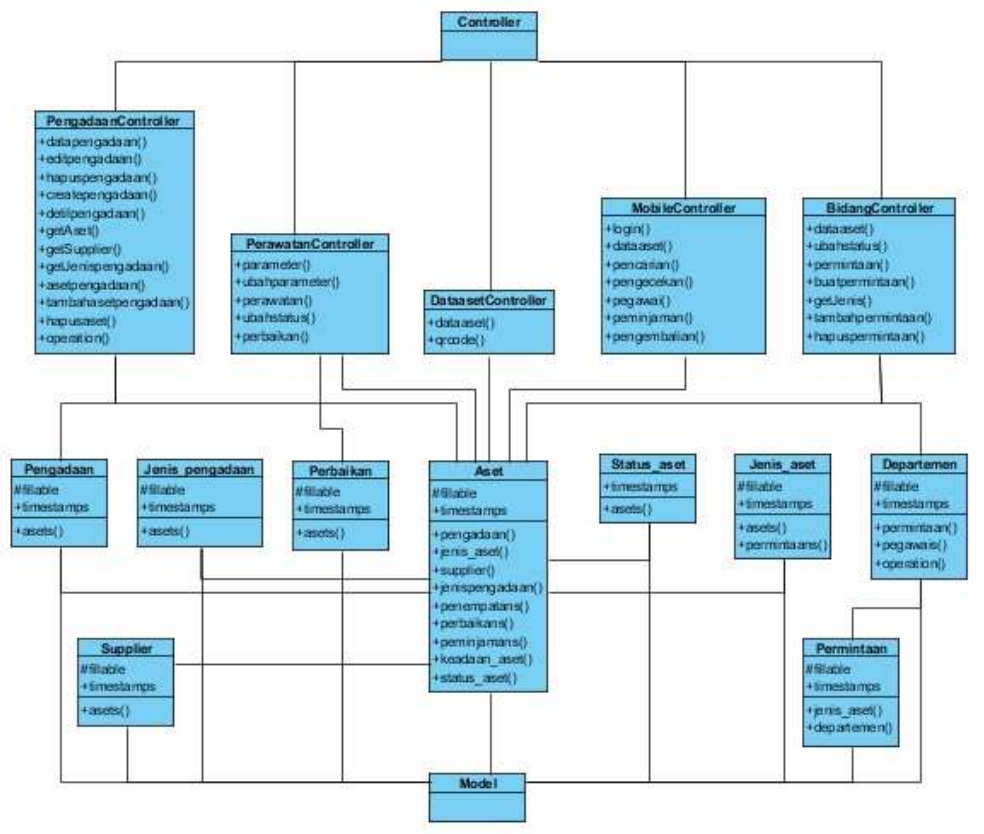

Gambar 11. Class Diagram 


\subsubsection{Perancangan Antarmuka}

Antarmuka adalah proses komunikasi antara pengguna (user) dengan sistem. Antarmuka pengguna (user interface) dapat menerima dan memberikan informasi kepada pengguna untuk membantu mengarahkan alur penelusuran masalah sampai ditemukan suatu solusi. Gambar 12 dibawah ini merupakan contoh dari disain antar muka untuk mengelola perawatan.

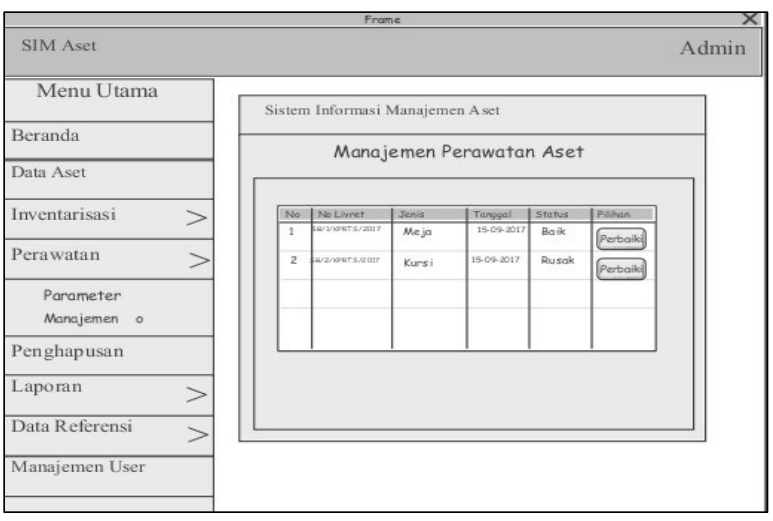

Gambar 12. Rancangan Antarmuka Mengelola Perawatan Aset

Salah satu rancangan antarmuka aplikasi mobile yang dibangun adalah halaman scanning $Q R$ Code. Rancangan antarmukan scan $Q R$ Code dapat dilihat pada Gambar 13.

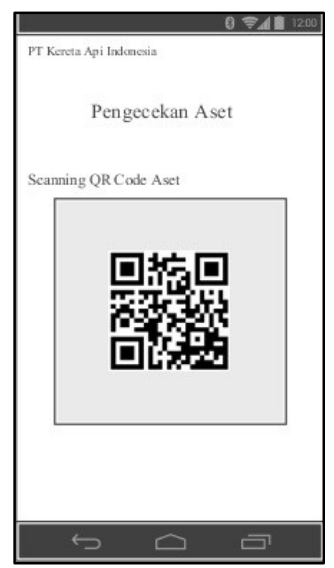

Gambar 13. Rancangan Antarmuka Scanning QR Code

\section{IMPLEMENTASI DAN PENGUJIAN}

Pada bagian ini dijelaskan tentang implementasi sistem sesuai dengan perancangan yang dilakukan pada bagian sebelumnya dan pengujian kesesuaian sistem yang dibangun dengan alur proses manajemen aset yang diusulkan.

\subsection{Implementasi Sistem}

Aplikasi sistem informasi manajemen aset dengan memanfaatkan teknologi $Q R$ Code ini difungsikan sebagai sistem yang mengelola dan menyajikan data dan informasi yang berkaitan dengan manajemen aset. Implementasi aplikasi web dibangun menggunakan bahasa pemrograman PHP (Pearl Hypertext Preprocessor) dan framework Laravel. Framework Laravel yang digunakan adalah Laravel versi 5.3, dan web server apache XAMPP versi 2.4.26. Web server berfungsi untuk menjalankan bahasa pemrograman PHP pada browser dan mengolah data pada database. Database yang digunakan sebagai tempat penyimpanan data adalah database MySQL. Implementasi aplikasi mobile dibangun menggunakan Android Studio IDE versi 2.3.3.

\subsubsection{Pengkodean Program}

Pada bagian pengkodean program ini dijelaskan kode program yang dibuat berdasarkan arsitektur aplikasi yang digunakan. Salah satu kode program yang dibangun adalah DataasetController. Kode program DataasetController dapat dilihat pada gambar 14 .

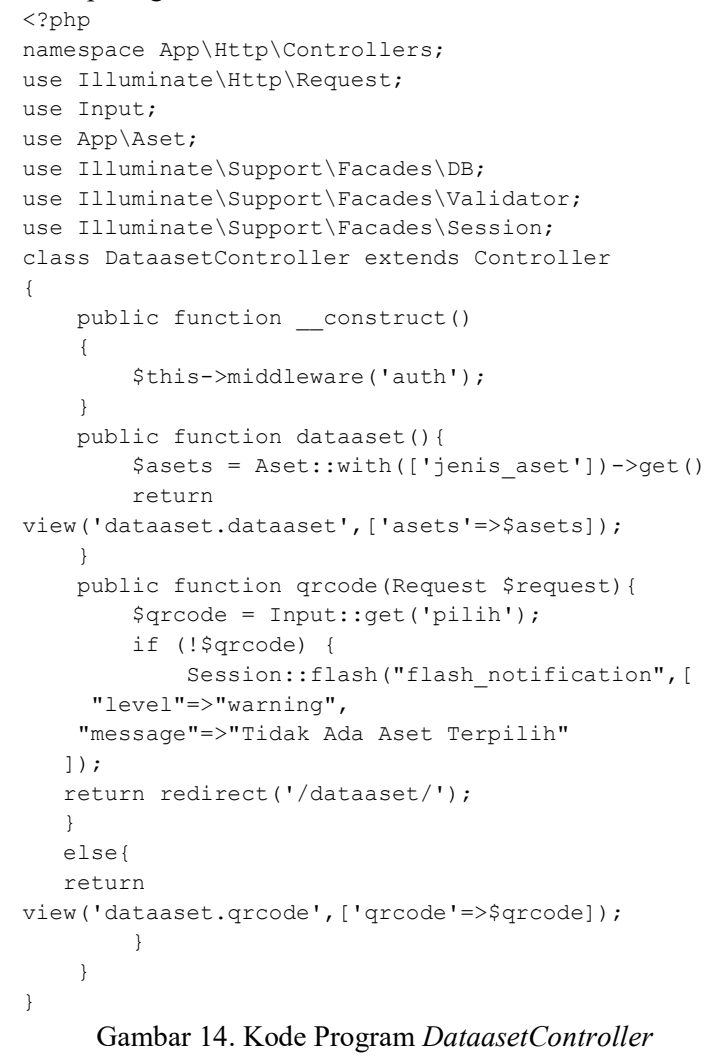

\subsubsection{Implementasi Antarmuka}

Implementasi antarmuka yang dibangun terdiri dari antarmuka aplikasi web dan mobile.

1. Implementasi Antarmuka Aplikasi Web

Aplikasi web yang dibangun dapat diakses oleh user menggunakan web browser. Salah satu implementasi yang dibangun adalah halaman utama (super admin). Implementasi halaman utama (super admin) dapat dilihat pada Gambar 15. 


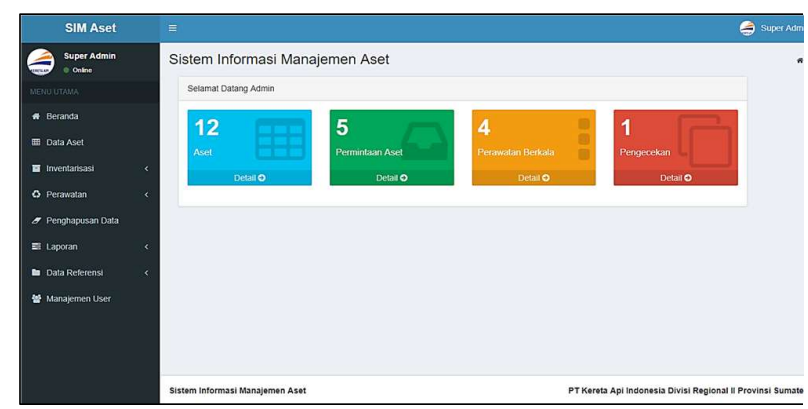

Gambar 15. Implementasi Antarmuka Halaman Utama

2. Implementasi Antarmuka Aplikasi Mobile

Aplikasi mobile yang dibangun dapat diakses oleh user menggunakan smartphone. Salah satu implementasi yang dibangun adalah halaman scanning $Q R$ Code. Implementasi halaman scan $Q R$ Code dapat dilihat pada Gambar 16.

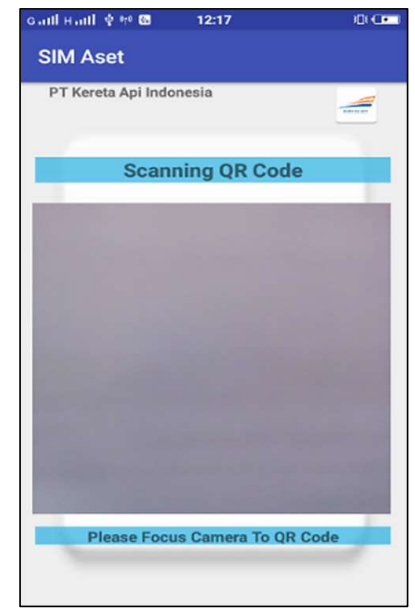

Gambar 16. Implementasi Antarmuka Halaman Scan QR Code

Tabel 10. Pengujian Tambah Data Pengadaan (Benar)

\begin{tabular}{ll}
\hline Kasus dan Hasil Uji (Benar) \\
\hline Data masukan & $\begin{array}{l}\text { Seluruh data yang dibutuhkan dalam } \\
\text { halaman tambah pengadaan }\end{array}$ \\
Yang & Sistem menampilkan halaman data \\
diharapkan & pengadaan dan notifikasi berhasil \\
Pengamatan & Dapat memilih dan menginput data \\
& pada halaman tambah pengadaan serta \\
& menekan tombol "Input Data" \\
Hasil & Sesuai \\
\hline
\end{tabular}

Tabel 11. Pengujian Tambah Data Pengadaan (Alternatif)

\begin{tabular}{|c|c|}
\hline \multicolumn{2}{|c|}{ Kasus dan Hasil Uji (Alternatif) } \\
\hline Data masukan & $\begin{array}{l}\text { User menekan tombol "Input Data" } \\
\text { sebelum mengisi form }\end{array}$ \\
\hline $\begin{array}{l}\text { Yang } \\
\text { diharapkan }\end{array}$ & $\begin{array}{l}\text { Sistem menampilkan notifikasi } \\
\text { kesalahan }\end{array}$ \\
\hline Pengamatan & $\begin{array}{l}\text { User tidak bisa menambah data } \\
\text { pengadaan }\end{array}$ \\
\hline Hasil & Sesuai \\
\hline
\end{tabular}

https://doi.org/10.25077/TEKNOSI.v6i3.2020.129-138

\subsection{Pengujian Sistem}

Pada tahapan ini dilakukan pengujian pada semua bagian aplikasi yang telah dibangun. Proses ini dilakukan agar aplikasi yang dibangun berjalan sesuai dengan perancangan sistem. Pengujian ini dilakukan dengan menggunakan metode black box testing, yaitu pengujian yang berfokus pada pemeriksaan ketersediaan fungsional yang sudah dirancang pada aplikasi. Salah satu pengujian yang dilakukan adalah pengujian tambah data pengadaan. Pengujian ini dibagi dalam 2 kondisi yaitu kondisi benar dan kondisi alternative (salah). Pengujian tambah data pengadaan dalam kondisi benar dapat dilihat pada tabel 3 dan pengujian altenatif dapat dilihat pada tabel 4. Untuk hasil pengujian tambah data pengadaan dapat dilihat pada Gambar 17, 18, dan 19.

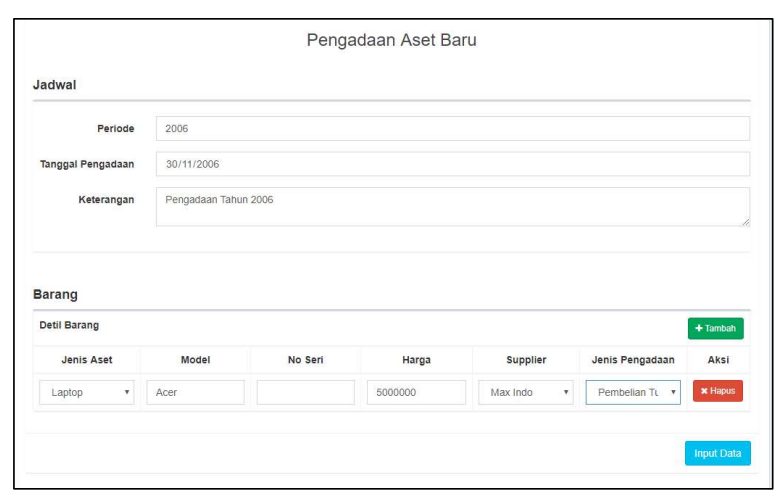

Gambar 17. Pengujian Masukan Tambah Data Pengadaan (Benar)

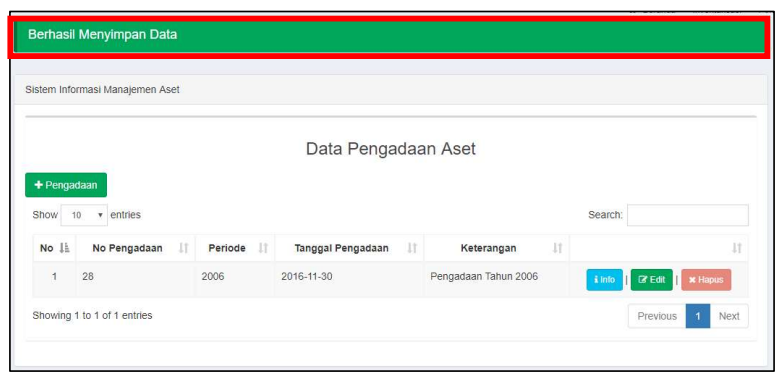

Gambar 18. Pengujian Keluaran Tambah Data Pengadaan (Benar)

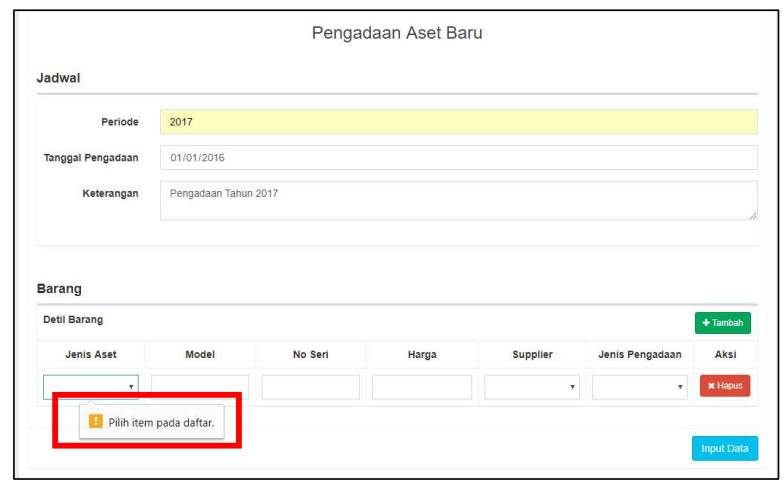

Gambar 19. Pengujian Tambah Data Pengadaan (Alternatif) 


\section{KESIMPULAN}

Pembuatan aplikasi web dan mobile untuk system informasi pengelolaan aset dengan memanfaatkan teknologi QR Code terlah berhasil dibangun. Pemanfaatan QR Code ini dirasakan sangat efektif karena sangat membantu user dalam hal melakukan inventarisasi aset dengan cepat dan tepat, yaitu hanya melalui pemindaian terhadap kode QR Code yang di tempel dimasing-masing aset, kemudian user hanya memasukkan kondisi aset tersebut dan data bisa langsung di submit ke server untuk disimpan. Pembangunan aplikasi ini menggunakan metode pengembangan system Waterfall, yang dimulai dengan tahapan Analisis yaitu dengan melakukan analisis terhadap system yang berjalan dan memberikan usulan terhadap system yang baru. Kemudian dilanjutkan dengan proses disain yaitu meracancang segala kebutuhan system, mulai dari usecase diagram, sequence diagram, class analisis dan class diagram, dilanjutkan dengan rancangan database, user interface web dan mobile. Tahapan terakahir yaitu dengan melakukan implementasi yaitu mentransformasikan hasil rancangan tadi kedalam bentuk codingan program dan melakukan pengujian terhadap aplikasi yang dibuat dengan menggunakan metode blackbox testing yaitu menguji fungsional system dengan kebutuhan aplikasi.

\section{DAFTAR PUSTAKA}

[1] Siregar, D.D., 2004, Manajemen Aset: Strategi Penataan Konsep Pembangunan Berkelanjutan secara Nasional dalam Konteks Kepala Daerah sebagai CEO's pada Era Globalisasi \& Otonomi Daerah. Jakarta: PT Gramedia Pustaka Utama

[2] Nugrahini, Y. (2012) 'Analisis Kinerja Pelaksanaan Kewajiban Pelayanan Publik Bidang Angkutan Kereta Api Penumpang Kelas Ekonomi', Jurnal Perencanaan Wilayah dan Kota, 23(1), pp. 19-36.

[3] Rahayu, Yeni Dwi, dkk. 2006. Pembuatan Aplikasi Pembacaan Quick Response Code Menggunakan Perangkat Mobile Berbasis J2ME Untuk Identifikasi Suatu Barang. Surabaya: Politeknik Elektronika Negeri Surabaya Institut Teknologi Sepuluh Nopember

[4] Pramihapsari, M. Kaldera, M. P. (2012) "Perancangan Labelling Pada Dokumen Menggunakan QR Code", Teknik Komputer, 20, pp. 59-67

[5] Rahmawati, A. Rahman, A. (2011) 'Sistem Pengamanan Keaslian Ijasah Menggunakan QR-Code dan Algoritma', Seminar, 1(2), pp. 105-112

[6] J. Arisa, M. Jasman. (2016). Rancang Bangun Sistem Informasi Manajemen Aset Sekolah Menggunakan Teknik Labelling QR Code (Studi Kasus: MAN 2 Model Pekanbaru). Jurnal Ilmiah Rekayasa dan Manajemen Sistem Informasi Vol. 2 No. 2.

[7] Akbar R, Silvana M, Zikri. A. (2019). Perancangan Model Bisnis Pembayaran Non Tunai untuk Pengelolaan Transaksi Jasa Laundry dengan Memanfaatkan Teknologi QR Code (Studi Kasus : Tiara Laundry). Jurnal Teknosi.Vol. 5, No. 3

[8] Pressman, R. S. (2001) Software Engineering A Practitioner's Approach 5th Ed-Roger S. Pressman.
[9] Haryani. (2015) 'Pemanfaatan Web Sistem Informasi Akademik Sebagai Pengontrol Nilai Siswa (Studi Kasus) MTS Pondok Modern Al-Islam Nganjuk'. 27(2). pp.52-53

[10] Pressman, R. S. (2009) Software Engineering A Practitioner's Approach 7th Ed - Roger S. Pressman.

[11] Rosa A. S, M. S. (2011). Modul Pembelajaran Rekayasa Perangkat Lunak (Terstruktur dan Berorientasi Objek). Modula. Bandung.

[12] Nugraha, M. P. dan Munir, R. 2011. Pengembangan Aplikasi QR Code Generator dan QR Code Reader dari Data Berbentuk Image. In Informatics National Conference (pp. 148-149). 